\title{
EFEKTIVITAS PENERAPAN SISTEM INFORMASI MANAJEMEN DAERAH (SIMDA) KEUANGAN DALAM PENYUSUNAN LAPORAN KEUANGAN DI DINAS ENERGI DAN SUMBER DAYA MINERAL (ESDM) PROVINSI JAMBI
}

\author{
Ridha Eka Putri ${ }^{1 *}$, Syahmardi Yacob ${ }^{2)}$ \\ ${ }^{1)}$ PNS pada Dinas ESDM Provinsi Jambi \\ ${ }^{2)}$ Staf Pengajar di Program Magister Manajemen Universitas Jambi \\ *Corresponding author: Afrandyudha@gmail.com
}

\begin{abstract}
Abstrak
Penelitian ini difokuskan pada efektivitas penerapan SIMDA Keuangan, serta faktor pendukung dan faktor penghambat efektivitas penerapan SIMDA Keuangan. Penelitian ini merupakan penelitian kualitatif dengan metode deskriptif. Penelitian ini dilakukan di Dinas ESDM Provinsi Jambi. Informan penelitian ditentukan dengan teknik Purposive. Data dalam penelitian ini dikumpulkan melalui wawancara, observasi dan studi dokumentasi. Hasil penelitian menunjukkan bahwa penerapan SIMDA Keuangan dalam penyusunan laporan keuangan di Dinas ESDM Provinsi Jambi dapat dinyatakan cukup efektif, meskipun terdapat beberapa kendala atau faktor penghambat dalam penerapan SIMDA Keuangan, seperti; jaringan server yang tidak stabil, belum adanya sistem backup otomatis, tidak adanya pemeliharan (maintenance) pada komputer dan perangkat SIMDA lainnya, kurangnya program pelatihan untuk peningkatan kualitas SDM, dan kurangnya komitmen pimpinan untuk memperhatikan perkembangan SIMDA Keuangan.
\end{abstract}

Kata Kunci : Efektivitas, Penerapan, SIMDA Keuangan, Laporan Keuangan

\begin{abstract}
This research is focused on how effective the implementation of SIMDA Finance, as well as supporting factors and factors inhibiting the effectiveness of implementing SIMDA Finance. This research is a qualitative research with descriptive method. This research was conducted at the Department of Energy and Mineral Resources of Jambi Province. The research informants were determined by using purposive technique. The data in this study were collected through interviews, observation and documentation study. The results showed that the application of the SIMDA Finance in the preparation of financial reports in the Department of Energy and Mineral Resources of Jambi Province can be declared quite effective, although there are several obstacles or inhibiting factors in the application of the SIMDA Finance, such as; Unstable server network, no automatic backup system, no maintenance on computers and other SIMDA devices, lack of training programs to improve the quality of human resources, and lack of leadership commitment to pay attention to the development of SIMDA Finance.
\end{abstract}

Keywords : Effectiveness, implementation, SIMDA Finance, Financial statements

\section{PENDAhULUAN}

Dalam rangka melaksanakan pertanggungjawaban keuangan, pemerintah daerah memiliki kewajiban untuk memanfaatkan teknologi informasi agar dapat mempermudah proses penyusunan laporan dan data keuangannya. Kewajiban pemanfaatan teknologi informasi oleh pemerintah daerah diatur dalam PP Nomor 56 tahun 2005 tentang Sistem Informasi Keuangan Daerah, bahwa pemerintah pusat dan pemerintah daerah 
berkewajiban untuk mengembangkan dan memanfatkan kemajuan teknologi informasi untuk meningkatkan kemampuan mengelola keuangan daerah dan menyalurkan informasi keuangan daerah kepada pelayanan publik. Atas dasar inilah BPKP kemudian mengembangkan aplikasi Sistem Informasi Manajemen Daerah (SIMDA) salah satunya yaitu SIMDA Keuangan dengan tujuan untuk mewujudkan akuntabilitas tata kelola pemerintahan khususnya di bidang pengelolaan dan pelaporan keuangan daerah. Untuk program SIMDA Keuangan, hingga 30 Juni 2020 telah diimplementasikan di 394 Pemda dari 542 Pemda yang ada.

Penerapan SIMDA Keuangan harus memenuhi beberapa kriteria sehingga dikatakan efektif. Efektivitas penerapan sistem informasi merupakan hasil yang di peroleh dari suatu instansi mencerminkan sejauh mana instansi tersebut mampu menghasilkan laporan keuangan secara tepat waktu, lengkap, akurat dan dapat diandalkan. Namun, dari hasil penelitian terdahulu seperti yang ditemukan oleh Pangestika dan Sari (2016); Setiaji (2017); dan Moentoro (2013) mengindikasikan bahwa penerapan SIMDA keuangan dalam penyusunan laporan keuangan daerah belum sepenuhnya dapat dinyatakan efektif.

Hasil temuan Badan Pemeriksa Keuangan (BPK) terhadap Laporan Keuangan Pemerintah Daerah (LKPD) seluruh pemerintah daerah mengungkapkan sebanyak 1.586 kasus temuan kelemahan sistem pengendalian akuntansi dan pelaporan pada 408 entitas, yang mengindikasikan masih belum baiknya kualitas dari laporan keuangan pemerintah daerah, seperti; proses penyusunan laporan tidak sesuai ketentuan, keterlambatan penyampaian laporan keuangan, dan sistem informasi akuntansi dan pelaporan tidak memadai dan belum didukung sumber daya manusia (SDM) yang memadai.

Pemerintah Provinsi Jambi sebagai pemerintah daerah telah menggunakan program aplikasi SIMDA Keuangan dalam sistem pengelolaan keuangan daerah sejak tahun 2014. Dalam rangka mengoptimalkan penggunaan SIMDA Keuangan di lingkup pemerintah Provinsi Jambi, BPKP Provinsi Jambi juga memberikan pembinaan terhadap sumber daya manusia di setiap Organisasi Pemerintah Daerah (OPD) Provinsi Jambi. Kegiatan pembinaaan ini sudah berjalan dengan efisien dengan tingkat pencapaian sasaran $100 \%$. Namun, masih juga ditemukan permasalahan di dalam penerapan SIMDA Keuangan seperti di salah satu Satuan Kerja Perangkat Daerah (SKPD) Provinsi Jambi, yaitu Dinas Energi dan Sumber Daya Mineral (ESDM) Provinsi Jambi.

Hasil temuan awal di Dinas Energi dan Sumber Daya Mineral (ESDM) Provinsi Jambi ditemukan kendala-kendala yang dihadapi dalam penerapan aplikasi SIMDA, diantaranya: yaitu masih ada pegawai bagian keuangan dan aset, baik itu bendahara maupun operator SIMDA Keuangan yang tidak bisa mengoperasikan aplikasi tersebut dengan alasan penggunaannya yang rumit karena selalu adanya pembaharuan atau update pada aplikasi SIMDA Keuangan, dan pusing karena data yang diinput terlalu banyak, sementara masih banyak pekerjaan lain yang harus diselesaikan, dan berbagai alasan lain. Akibat keterbatasan pegawai yang bisa menggunakan SIMDA Keuangan ini menyebabkan keterlambatan dalam menginput data realisasi, maka laporan keuangan tidak dapat diselesaikan dengan cepat sehingga menghambat tercapainya sasaran kerja.

Permasalahan lainnya terkait penerapan SIMDA Keuangan di Dinas ESDM Provinsi Jambi yaitu proses rekonsiliasi kas yang diakibatkan oleh sistem yang tidak terintegrasi dengan baik dan permasalahan server database yang ada di instansi ini. SIMDA Keuangan yang tidak terintegrasi dengan rekening kas dapat menyebabkan beberapa masalah. Pertama, masalah proses input data realisasi penggunaan anggaran yang terhambat prosesnya akibat harus menunggu rekonsiliasi kas. Rekonsiliasi kas ini harus dilaksanakan akibat data realisasi penggunaan anggaran yang telah diinput tidak sesuai dengan data 
rencana penggunaan anggaran yang terdapat di sistem keuangan BPKP. Oleh karena itu, perlu dilakukan pengkajian lebih jauh mengenai efektivitas penerapan SIMDA keuangan dalam penyusunan laporan keuangan di Dinas Energi dan Sumber Daya Mineral (ESDM) Provinsi Jambi.

\section{METODE PENELITIAN}

Penelitian ini menggunakan pendekatan penelitian kualitatif yang bermaksud untuk memahami fenomena efektivitas penerapan SIMDA Keuangan dalam penyusunan laporan keuangan di Dinas Energi dan Sumber Daya Mineral (ESDM) Provinsi Jambi. Adapuan fokus dalam penelitian ini, yaitu efektivitas penerapan SIMDA Keuangan meliputi; (1) keberhasilan program, (2) keberhasilan sasaran, (3) kepuasan terhadap program, dan (4) pencapaian tujuan secara menyeluruh (Campbell dalam Shabrina, 2014), serta faktor pendukung maupun faktor penghambat efektivitas penerapan SIMDA Keuangan di Dinas ESDM Provinsi Jambi. Data dalam penelitian ini diperoleh melalui triangulasi teknik yaitu wawancara, observasi, dan dokumentasi. Data yang diperoleh kemudian dianalisis menggunakan teknik analisis data kualitatif model analisis interaktif.

\section{HASIL DAN PEMBAHASAN}

Efektivitas Penerapan Sistem Informasi Manajemen Daerah (SIMDA) Keuangan dalam penyusunan laporan keuangan di Dinas Energi dan Sumber Daya Mineral (ESDM) Provinsi Jambi

Mengutip teori efektivtas program menurut Campbell (Shabrina, 2014), efektivitas penerapan SIMDA Keuangan di Dinas ESDM Provinsi Jambi, ditinjau dari aspek keberhasilan program, keberhasilan sasaran, kepuasan terhadap program, dan pencapaian tujuan secara menyeluruh.

\section{Keberhasilan Program}

Hasil temuan terkait keberhasilan penerapan SIMDA Keuangan didapatkan bahwa aplikasi SIMDA Keuangan sudah berjalan dengan maksimal dan sesuai dengan tujuan dan prosedur penerapan SIMDA Keuangan di Dinas ESDM Provinsi Jambi. Keberhasilan dari SIMDA Keuangan sesuai dengan teori yang dikemukakan Campbell (dalam Shabrina, 2014) bahwa keberhasilan suatu program dapat dilihat dari kualitas program tersebut, apakah sudah berjalan dengan maksimal atau belum.

Keberhasilan ini dibuktikan dari keterangan yang diperoleh dari hasil wawancara dengan narasumber, dimana aplikasi SIMDA Keuangan mampu menghasilkan laporan keuangan dan segala bukti pendukung yang lebih lengkap dan cepat daripada sistem sebelumnya atau cara manual. Selain itu, pengolahan data transaksi keuangan melalui aplikasi SIMDA Keuangan menjadi laporan keuangan dapat dilakukan dengan benar dan sesuai dengan standar akuntansi pemerintah. Penggunaan aplikasi SIMDA Keuangan juga mampu menghasilkan informasi keuangan yang sesuai dengan kebutuhan untuk memantau posisi keuangan dan kinerja yang telah dicapai oleh Dinas ESDM Provinsi Jambi.

Menurut Kumarotomo (dalam Febria, dkk, 2018) tujuan lainnya dari dibentuknya sistem informasi manajemen adalah agar organisasi dapat memiliki informasi yang bermanfaat dalam pembuatan keputusan yang strategis. Merujuk pada teori yang dinyatakan Kumarotomo, keterangan yang diperoleh dari narasumber membuktikan bahwa tujuan lain dari penggunaan SIMDA Keuangan juga telah tercapai, dimana informasi yang dihasilkan oleh aplikasi SIMDA Keuangan dapat mendukung proses pengambilan keputusan dan bisa digunakan untuk analisis laporan keuangan lebih lanjut. 


\section{Keberhasilan Sasaran}

Hasil temuan terkait keberhasilan sasaran dari penerapan SIMDA Keuangan didapatkan bahwa penerapan aplikasi SIMDA Keuangan sangat membantu Dinas ESDM Provinsi Jambi dalam mencapai sasarannya untuk menghasilkan laporan keuangan dengan cepat, dan akurat. Keberhasilan sasaran dari penerapan SIMDA Keuangan ini sesuai dengan teori yang dikemukakan Campbell (dalam Shabrina, 2014) bahwa keberhasilan penerapan suatu program dapat dilihat dari sudut pencapaian tujuan dengan memusatkan perhatian terhadap output yang dihasilkan program tersebut, artinya keberhasilan sasaran dapat diukur dengan seberapa jauh tingkat kualitas output yang dihasilkan dari program atau sistem yang digunakan organisasi untuk mencapai sasaran yang telah ditetapkan.

Berdasarkan keterangan yang diperoleh dari narasumber, aplikasi SIMDA Keuangan mampu manghasilkan informasi laporan keuangan dengan ketepatan atau tingkat kebenaran yang lebih baik bila dibandingkan dengan pengolahan data manual. Hasil temuan dalam penelitian ini relevan dengan hasil penelitian Hardjanto, dkk (2019), dimana aplikasi SIMDA keuangan menghasilkan informasi laporan keuangan dan informasi keuangan lainnya dengan kualitas relevansi, akurasi dan ketepatan waktu yang lebih baik daripada pengolahan dengan sistem sebelumnya.

Keberhasilan organisasi di dalam pengelolaan anggaran yang telah diserap, salah satunya dapat dilihat dari kualitas laporan keuangan yang dihasilkan. Berdasarkan keterangan yang diperoleh dari narasumber, didapatkan bahwa keberhasilan yang dicapai dari penerapan SIMDA keuangan dalam penyusunan laporan keuangan di Dinas ESDM Provinsi Jambi yaitu didapatkannya penilaian laporan keuangan dengan kriteria Wajar Tanpa Pengecualian (WTP), yang berarti informasi keuangan yang disajikan pada laporan keuangan dapat dipahami, relevan, dapat dipercaya, dan dapat dibandingkan.

\section{Kepuasan terhadap Program}

Hasil temuan terkait kepuasan terhadap program SIMDA Keuangan didapatkan bahwa kepuasan pengguna terhadap aplikasi SIMDA Keuangan di Dinas ESDM Provinsi Jambi sudah bisa dikatakan cukup karena seluruh menu dan fitur yang ada pada aplikasi SIMDA Keuangan bermanfaat dan mempermudah pekerjaan pengguna dalam mengelola keuangan dan menyusun laporan keuangan. Menurut Campbell (dalam Shabrina, 2014) kepuasan merupakan kriteria efektivitas yang mengacu pada keberhasilan program dalam memenuhi kebutuhan pengguna.

Berdasarkan keterangan yang diperoleh dari narasumber, tampilan dan prosedur di dalam aplikasi SIMDA Keuangan sederhana dan mudah untuk dioperasikan oleh pengguna dalam menghasilkan informasi atau dokumen baik di bidang penganggaran, penatausahaan, dan akuntansi dan pelaporan. Selain itu, aplikasi SIMDA Keuangan didukung buku manual sistem dan prosedur yang sangat lengkap, sehingga memudahkan untuk menghasilkan informasi atau dokumen yang dibutuhkan. Untuk kemudahan yang dirasakan pengguna aplikasi SIMDA Keuangan dalam penyusunan laporan keuangan dapat dilihat dari keterangan yang diberikan narasumber yaitu; (1) kemudahan proses penyajian RKA, DPA dan SKPD dalam prosedur panganggaran pada aplikasi SIMDA keuangan, (2) kemudahan dalam proses penginputan bukti penerimaan dan surat tanda setoran dalam prosedur penatausahaan pada aplikasi SIMDA keuangan, dan (3) kemudahan dalam penyajian laporan keuangan yang sesuai dengan standar akuntansi pemerintah.

\section{Pencapaian Tujuan secara Menyeluruh}

Menurut Hidayat (2018) pencapaian tujuan yang didapatkan dengan penerapan 
SIMDA dapat dilihat dengan seberapa jauh target (kualitas, kuantitas dan waktu) yang tercapai.

\section{1) Kuantitas SIMDA Keuangan}

Hasil temuan terkait kuantitas SIMDA Keuangan didapatkan bahwa penggunaan aplikasi SIMDA Keuangan di Dinas ESDM Provinsi Jambi dapat menghasilkan output sesuai dengan jumlah output yang ditargetkan baik dibidang penganggaran, penatausahaan, perbendaharaan dan akuntansi dan pelaporan. Hasil temuan ini sesuai dengan teori yang dikemukakan Hidayat (2018) bahwa baik tidaknya kuantitas dari suatu sistem informasi, dapat dilihat dari apakah jumlah output yang dihasilkan dari sistem tersebut sesuai dengan jumlah output yang dibutuhkan pengguna sistem tersebut.

\section{2) Kualitas SIMDA Keuangan}

Menurut Hidayat (2018) kualitas suatu program dilihat dari output yang dihasilkan oleh program tersebut. Jika output yang dihasilkan tidak sesuai dengan manfaat yang diharapkan maka kebijakan penggunaan program tersebut tidak akan berjalan dengan baik. Hasil temuan terkait kualitas SIMDA Keuangan didapatkan bahwa aplikasi SIMDA Keuangan dapat membantu Dinas ESDM Provinsi Jambi dalam menghasilkan laporan keuangan yang dapat dipahami, relevan, dapat dipercaya, dan dapat dibandingkan.

Dinyatakan dapat dipercaya karena berdasarkan keterangan yang diperoleh dari narasumber, aplikasi SIMDA Keuangan telah memberikan fungsi verifikasi pada dokumen keuangan yang telah diproses sehingga kebenaran dalam dokumen tersebut dapat lebih dipercaya. Format atau konsep pengisian dokumen laporan keuangan juga sudah ada di lembar kerja Aplikasi SIMDA Keuangan, sehingga kualitas data dan informasi yang dihasilkan melalui SIMDA Keuangan menjadi lebih akurat.

Dinyatakan relevan, karena informasi laporan keuangan yang dihasilkan dari SIMDA Keuangan memiliki manfaat umpan balik, memiliki manfaat prediktif, dan lengkap. Dikatakan ada manfaat umpan balik nya didasarkan keterangan dari narasumber bahwa aplikasi ini memungkinkan pengguna laporan keuangan untuk menggunakan informasi tersebut dalam pengambilan keputusan terkait dengan pengelolaan keuangan di masa depan, maupun untuk dijadikan sebagai bahan evaluasi atas pengelolaan keuangan di masa kini dan masa lalu. Sementara manfaat prediktif ini didasarkan keterangan dari narasumber bahwa informasi pada laporan keuangan Dinas ESDM Provinsi Jambi dapat membantu pimpinan dan staf keuangan untuk memprediksi masa yang akan datang berdasarkan hasil laporan dimasa lalu dan kejadian masa sekarang. Dan untuk kelengkapannya sendiri, laporan yang dihasilkan oleh SIMDA Keuangan sudah dikelompokan menurut jenis masing-masing dengan sistem informasi yang langsung bekerja otomatis setelah data diinput.

\section{3) Ketepatan Waktu}

Hasil penelitian menunjukkan bahwa penerapan SIMDA Keuangan membuat informasi laporan keuangan yang dihasilkan oleh Dinas ESDM Provinsi Jambi menjadi lebih baik dalam aspek ketepatan waktu. Hal ini dibuktikan dari keterangan yang disampaikan narasumber bahwa penyusunan laporan keuangan melalui aplikasi SIMDA Keuangan di Dinas ESDM Provinsi Jambi, dapat dilakukan tepat waktu sesuai dengan deadline yang telah ditentukan.

Ketepatan waktu dalam penelitian ini juga diukur berdasarkan perbandingan waktu standar menurut Permendagri Nomor 13 Tahun 2006 dengan waktu faktual setiap proses penyelesaian satu produk SIMDA Keuangan. Pulungan (2014) dalam penelitiannya 
mengungkapkan bahwa perbandingan waktu faktual dan waktu standar akan menentukan tingkat implementasi SIMDA, dengan asumsi bahwa; (1) jika waktu standar lebih lama dibandingkan waktu faktual, maka SIMDA telah dapat diimplementasikan dengan baik. (2) Jika waktu faktual lebih lama dibanding waktu standar, maka SIMDA belum dapat diimplementasikan dengan baik.

Hasil observasi waktu faktual penerapan SIMDA Keuangan pada bidang penganggaran didapatkan bahwa rata-rata waktu yang dibutuhkan untuk pembuatan Rencana Kerja Anggaran (RKA) dan Dokumen Pelaksanaan Anggaran (DPA) yaitu 3,66 hari. Sementara pada bidang penatausahaan, rata-rata waktu yang dibutuhkan untuk pembuatan Surat Perintah Pembayaran (SPP), Surat Perintah Membayar (SPM), Surat Perintah Penyediaan Dana (SP2D), dan Surat Tanda Setoran (STS), yaitu 1,39 hari. Dengan demikian waktu faktual dari output yang dihasilkan pada masing-masing bidang di bawah waktu standar yang ditetapkan Permendagri Nomor 13 Tahun 2006.

\section{Faktor Pendukung Efektivitas Penerapan Sistem Informasi Manajemen Daerah (SIMDA) Keuangan dalam penyusunan laporan keuangan di Dinas Energi dan Sumber Daya Mineral (ESDM) Provinsi Jambi}

Penerapan SIMDA Keuangan yang dilakukan oleh Dinas Energi dan Sumber Daya Mineral (ESDM) Provinsi Jambi tentunya tidak lepas dari prakondisi yang menjadi faktor pendukungnya. Dari hasil Penelitian, berbagai faktor pendukung yang dimiliki untuk menerapkan SIMDA Keuangan pada Dinas Energi dan Sumber Daya Mineral (ESDM) Provinsi Jambi adalah sebagai berikut:

\section{Komunikasi}

Komunikasi merupakan salah satu faktor keberhasilan implementasi kebijakan masyarakat, dimana komunikasi ini ditujukan agar implementor mengetahui apa yang harus dilakukan, dimana yang menjadi tujuan dan sasaran kebijakan harus ditransmisikan kepada kelompok sasaran, sehingga akan mengurangi distorsi implementasi (Edward, 2011:90-92). Berdasarkan hasil wawancara didapatkan bahwa penerapan SIMDA Keuangan yang optimal pada Dinas Energi dan Sumber Daya Mineral (ESDM) Provinsi Jambi didukung oleh adanya komunikasi atau sosialisasi yang aktif baik dari atasan kepada pegawai maupun antar pegawai.

\section{Sumber Daya Manusia}

Edward (2011:90-92) menyatakan bahwa meskipun isi kebijakan telah dikomunikasikan secara jelas dan konsisten, tetapi apabila implementor kekurangan sumber daya manusia untuk melaksanakan, maka implementasi tidak akan berjalan efektif. Berdasarkan hasil wawancara didapatkan bahwa penerapan SIMDA Keuangan di Dinas ESDM Provinsi Jambi didukung oleh adanya sumber daya manusia yang telah memiliki kapasitas kemampuan atau keahlian untuk mengoperasikan SIMDA Keuangan.

Keahlian dari para pelaksana menjadi salah satu komponen penting sumber daya untuk penerapan kebijakan, oleh karena itu, jika jumlah staff pelaksana kebijakan terbatas maka hal yang harus dilakukan yaitu meningkatkan kemampuan/keterampilan para pelaksana untuk menjalankan kebijakan. Dari keterangan yang disampaikan narasumber, peningkatan keahlian pegawai yang terlibat dalam penyusunan laporan keuangan melalui SIMDA Keuangan, dilakukan melalui pelatihan, diskusi yang lebih khusus, serta kordinasi antara pimpinan dan pegawai (staff) Dinas ESDM Provinsi Jambi. Hasil penelitian ini mendukung penelitian Saleh (2015) yang menyatakan bahwa adanya peningkatan SDM melalui pelatihan untuk meningkatkan pemahaman dan pengetahuan SDM terhadap 
SIMDA Keuangan.

\section{Disposisi/Sikap}

Edward (2011:90-92) menyatakan bahwa salah satu faktor yang mempengaruhi efektifitas penerapan kebijakan adalah sikap implementor. Jika implementor setuju dengan isi dari kebijakan maka mereka akan melaksanakan dengan senang hati, tetapi jika pandangan mereka berbeda dengan pembuat kebijakan, maka proses penerapan akan mengalami banyak masalah. Dari hasil wawancara didapatkan bahwa penerapan SIMDA Keuangan di Dinas ESDM Provinsi Jambi didukung oleh sikap seluruh pegawai yang menerima dan mampu melaksanakan kebijakan penerapan SIMDA Keuangan dengan baik dan senang hati selaku implementor kebijakan. Disposisi/sikap yang baik dari implementor dikarenakan menurut mereka SIMDA Keuangan dapat mempercepat proses pelaporan keuangan. Selain itu, ada juga yang berpandangan bahwa penerapan SIMDA Keuangan sangat membantu dan membuat pekerjaan penyusunan laporan keuangan menjadi lebih efektif dan efisien.

\section{Struktur Birokrasi}

Edward (2011:90-92) menyatakan bahwa kebijakan yang kompleks membutuhkan kerjasama banyak orang. Unsur yang mungkin berpengaruh terhadap suatu organisasi dalam penerapan kebijakan salah satunya adalah tingkat pengawasan terhadap keputusankeputusan sub unit dan proses-proses dalam badan pelaksana. Selain itu, untuk menciptakan sebuah aransemen kebijakan yang ideal jika tidak didukung oleh nilai-nilai moral dan kapasitas pejabat yang baik maka kebijakan tersebut tidak akan berjalan dengan baik dan bermanfaat (Sudiyono, 2007).

Hasil wawancara terkait dengan faktor struktur birokrasi didapatkan bahwa Penerapan SIMDA Keuangan di Dinas ESDM Provinsi Jambi didukung oleh struktur birokrasi yang baik. Hal ini dilihat dari adanya tingkat pengawasan hierarkis terhadap keputusan sub unit dan proses pelaksanaan penerapan SIMDA Keuangan pada Dinas ESDM Provinsi Jambi yang sudah cukup baik. Berdasarkan keterangan dari narasumber diketahui bahwa setiap penanggungjawab SIMDA Keuangan di Dinas ESDM Provinsi Jambi saling bekerjasama melakukan pengawasan secara rutin agar laporan keuangan yang dihasilkan melalui SIMDA Keuangan, sehingga hambatan atau masalah yang terjadi pada program dapat teratasi dan laporan keuangan dapat diselesaikan tepat waktu.

\section{Faktor Penghambat Efektivitas Penerapan Sistem Informasi Manajemen Daerah (SIMDA) Keuangan dalam penyusunan laporan keuangan di Dinas Energi dan Sumber Daya Mineral (ESDM) Provinsi Jambi}

Dalam penerapannya, penggunaan SIMDA Keuangan di Dinas Energi dan Sumber Daya Mineral (ESDM) Provinsi Jambi tidak selalu berjalan sesuai dengan apa yang diharapkan, karena terdapat beberapa kendala atau hambatan dalam pelaksanaannya sehingga menyebabkan penerapan aplikasi SIMDA Keuangan tidak berjalan dengan optimal. Adapun faktor penghambat yang selama ini masih menjadi masalah dalam penerapan SIMDA Keuangan untuk penyusunan laporan keuangan di Dinas Energi dan Sumber Daya Mineral (ESDM) Provinsi Jambi yaitu:

\section{Software dan Jaringan}

Masalah terkait software dan jaringan merupakan masalah yang paling krusial dan paling dibahas oleh para narasumber, karena hampir semua narasumber mengeluhkan tentang hal ini. Hasil penelitian terkait faktor software dan jaringan ditemukan bahwa 
kendala utama pada software dan jaringan SIMDA Keuangan yaitu jaringan server yang tidak stabil sehingga aplikasi sulit untuk diakses secara real time, serta belum adanya sistem backup otomatis untuk mengatasi masalah data hilang atau corrupt. Menurut Nugroho (2008) permasalahan software dan jaringan merupakan salah satu faktor yang dapat menghambat efektivitas penerapan suatu program.

Hasil penelitian ini relevan dengan hasil penelitian Febria, dkk (2018), dimana gangguan jaringan merupakan salah satu faktor penghambat efektivitas penerapan SIMDA Keuangan, yang menyebabkan data yang telah diinput ke SIMDA tidak dapat tersimpan sehingga pegawai harus menginput data ulang. Gangguan jaringan juga menyebabkan user tidak dapat masuk ke SIMDA.

\section{Sarana dan Prasarana}

Sarana dan prasarana yang dimaksud dalam penelitian ini adalah perangkat keras (hardware) SIMDA Keuangan di Dinas ESDM Provinsi Jambi. Hardware yang digunakan pada pengoperasian SIMDA pada dasarnya terdiri atas set komputer/laptop, perangkat jaringan, serta server database. Dan setiap komponen ini ditemui banyak masalah yang bisa berakibat fatal pada data yang tersimpan di database. Menurut Madjid (2011) kekurangan jumlah atau kurangnya spesifikasi yang ada pada hardware komputer dalam instansi dapat menyebabkan masalah pada sistem atau program yang digunakan.

Hasil wawancara terkait permasalahan hardware SIMDA Keuangan di Dinas ESDM Provinsi Jambi, didapatkan bahwa kendala utama yang dihadapi yaitu komputer dan perangkat keras (hardware) SIMDA Keuangan sering mengalami kerusakan atau error sehingga menghambat aktivitas penyusunan laporan keuangan. Hal ini dikarenakan tidak adanya pemeliharan (maintenance) pada komputer dan perangkat SIMDA lainnya.

Tidak adanya pemeliharan (maintenance) pada hardware SIMDA Keuangan dikarenakan belum adanya penempatan pos anggaran khusus untuk pemeliharaan (maintenance) hardware SIMDA Keuangan untuk tahun 2020. Permasalahan hardware lainnya yang cukup serius yaitu tidak adanya perangkat yang bisa melindungi server database dari resiko data hilang (data loss). Hasil penelitian ini relevan dengan hasil penelitian Agnes, dkk (2019) yang menyatakan bahwa pada SIMDA di instansi BPKAD juga belum terdapat sistem backup otomatis sebagai pendukung hardware server. Backup otomatis sebenarnya merupakan sistem standar yang menjadi suport untuk server database, yang jikalau data mengalami masalah (hilang atau corrupt), bisa dikembalikan lagi seperti semula. Ketiadaan sistem pendukung server ini juga menjadi masalah besar, karena ketika data hilang atau corrupt sekarang, maka akan sangat sulit untuk dikembalikan lagi seperti semula.

\section{Sumber Daya Manusia}

Hasil penelitian terkait faktor sumber daya manusia ditemukan permasalahan atau kendala yaitu kurang telitinya operator dalam melakukan input data, seperti kesalahan memasukan kode rekning, akibatnya data yang diinput tidak sesuai. Hasil penelitian ini relevan dengan hasil penelitian Febria, dkk (2018) yang mengungkapkan bahwa adanya faktor kelalaian manusia yang menghambat efektivitas penerapan SIMDA seperti kesalahan input data. Hertanto, dkk (2016) dalam penelitiannya juga mengungkapkan bahwa permasalahan sumber daya manusia selaku operator masih belum maksimal dalam pengoperasian SIMDA Keuangan. Menurut Nugroho (2008) kelalaian manusia (human error) merupakan faktor lainnya yang dapat menghambat efektivitas penerapan program. Permasalahan SDM lainnya yaitu kurangnya komitmen pegawai (penanggung jawab) dalam mengoperasikan SIMDA Keuangan, yang ditandai dengan perilaku menunda 
pekerjaan input data secara real time pada SIMDA Keuangan, serta rendahnya motivasi pegawai untuk meningkatkan pengetahuannya tentang pengoperasian SIMDA Keuangan.

\section{Komitmen Pimpinan}

Dalam penerapan SIMDA keuangan di Dinas ESDM Provinsi Jambi, bahwa komitmen yang kuat dari pimpinan untuk meningkatkan performa SIMDA baik dari segi kualitas sistem dan SDM belum nampak. Hal ini terungkap dari keterangan yang disampaikan informan bahwa belum adanya penempatan pos anggaran khusus untuk pelatihan tentang SIMDA Keuangan, dan anggaran khusus untuk pemeliharaan (maintenance) hardware SIMDA Keuangan. Kurangnya komitmen pimpinan juga terlihat dari kurang tanggapnya pimpinan dalam merespon permasalahan teknik maupun non teknik terkait penyusunan laporan keuangan menggunakan SIMDA Keuangan. Selain itu, belum adanya upaya pimpinan untuk menyediakan sumber daya manusia yang kompeten di bidang IT untuk mengatasi permasalahan teknis aplikasi SIMDA Keuangan.

Ramadhan (2013) menekankan dalam penemuannya, bahwa komitmen pimpinan juga menjadi masalah dalam penerapan suatu sistem. Hal ini karena pimpinan belum secara pro aktif dalam meminta informasi dan dalam proses pengembangan sistem untuk menghasilkan informasi laporan manajerial lainnya. Hal ini terlihat dari setelah beberapa tahun berlakunya SIMDA Keuangan di BPKAD Provinsi Sulut, anggaran untuk peningkatan kualitas SDM serta pos-pos khusus untuk anggaran pengembangan SIMDA masih belum ada. Agnes, dkk (2019) dalam penelitiannya mengungkapkan rendahnya komitmen atasan untuk memperhatikan perkembangan SIMDA Keuangan, terlihat dari kurangnya anggaran untuk peningkatan performa sistem, anggaran untuk peningkatan kapabilitas karyawan, serta anggaran untuk mengembangkan sarana-prasarana terkait SIMDA.

\section{SIMPULAN DAN SARAN}

\section{Simpulan}

1. Penerapan SIMDA Keuangan dalam penyusunan laporan keuangan di Dinas ESDM Provinsi Jambi dapat dinyatakan cukup efektif, meskipun terdapat beberapa kendala atau faktor penghambat dalam penerapan SIMDA Keuangan. Hal ini ditandai dengan terpenuhinya kriteria efektivitas penerapan SIMDA Keuangan baik dari aspek keberhasilan program, keberhasilan sasaran, kepuasan terhadap program, dan pencapaian tujuan secara menyeluruh.

2. Faktor-faktor pendukung efektivitas penerapan SIMDA Keuangan dalam penyusunan laporan keuangan di Dinas ESDM Provinsi Jambi, meliputi :

a. Komunikasi

Penerapan SIMDA Keuangan di Dinas ESDM Provinsi Jambi didukung oleh adanya komunikasi atau sosialisasi yang aktif, baik dari pimpinan kepada pegawai, maupun dari BPKP.

b. Sumber daya manusia

Penerapan SIMDA Keuangan di Dinas ESDM Provinsi Jambi didukung oleh adanya sumber daya manusia yang telah memiliki kapasitas untuk mengoperasikan SIMDA Keuangan.

c. Disposisi/sikap

Penerapan SIMDA Keuangan di Dinas ESDM Provinsi Jambi didukung oleh sikap seluruh pegawai yang menerima dan mampu melaksanakan kebijakan penerapan SIMDA Keuangan dengan baik dan senang hati selaku implementor kebijakan.

d. Strukur birokrasi 
Penerapan SIMDA keuangan di Dinas ESDM Provinsi Jambi didukung oleh struktur birokrasi yang baik. Hal ini dikarenakan setiap penanggungjawab SIMDA Keuangan selalu berpegang pada nilai-nilai, yaitu: integritas, komitmen, ketulusan, dan sinergi.

3. Faktor-faktor penghambat efektivitas penerapan SIMDA Keuangan dalam penyusunan laporan keuangan di Dinas ESDM Provinsi Jambi, meliputi:

a. Software dan jaringan

Kendala utama pada software dan jaringan SIMDA Keuangan yaitu jaringan server yang tidak stabil sehingga aplikasi sulit untuk diakses secara real time, serta belum adanya sistem backup otomatis untuk mengatasi masalah data hilang atau corrupt.

b. Sarana dan prasarana

Kendala utama pada sarana dan prasarana SIMDA Keuangan di Dinas ESDM Provinsi Jambi yaitu komputer dan perangkat keras (hardware) SIMDA Keuangan sering mengalami kerusakan atau error sehingga menghambat aktivitas penyusunan laporan keuangan. Hal ini dikarenakan tidak adanya pemeliharan (maintenance) pada komputer dan perangkat SIMDA lainnya.

c. Sumber daya manusia

Kendala utama pada sumber daya manusia di Dinas ESDM Provinsi Jambi yaitu kurangnya komitmen pegawai (penanggung jawab) dalam mengoperasikan SIMDA Keuangan, yang ditandai dengan perilaku menunda pekerjaan input data secara real time pada SIMDA Keuangan, serta rendahnya motivasi pegawai untuk meningkatkan pengetahuannya tentang pengoperasian SIMDA Keuangan.

d. Komitmen pimpinan

Kendala pada komitmen atasan untuk memperhatikan perkembangan SIMDA Keuangan, terlihat dari; (1) belum adanya penempatan pos anggaran khusus untuk pelatihan tentang SIMDA Keuangan dan pemeliharaan (maintenance) hardware SIMDA Keuangan, (2) kurang tanggapnya pimpinan dalam merespon permasalahan teknik maupun non teknik terkait penyusunan laporan keuangan menggunakan SIMDA Keuangan, dan (3) belum adanya upaya pimpinan untuk menyediakan sumber daya manusia yang kompeten di bidang IT untuk mengatasi permasalahan teknis aplikasi SIMDA Keuangan.

\section{Saran}

Untuk mengatasi kendala pada software dan jaringan Dinas ESDM Provinsi Jambi dan BPKP Provinsi Jambi harus melakukan pengadaan perangkat penunjang berupa sistem backup data untuk meminimalisir resiko data loss yang biasa terjadi karena penurunan performa hardisk ataupun disk pada server. Selain itu, perlu adanya peninjauan kembali dari BPKP Provinsi Jambi maupun BPKP pusat selaku pengembang aplikasi SIMDA terkait dengan masalah sulitnya memberikan keluhan dan umpan balik mengenai masalah software dan jaringan pada server SIMDA.

Dalam mengatasi kendala pada hardware sistem, perlu adanya perhatian dari pimpinan untuk menganggarkan pemeliharan (maintenance) pada komputer dan perangkat SIMDA lainnya yang ada di Dinas ESDM Provinsi Jambi.

Untuk mengatasi kendala sumber daya manusia, perlu adanya perhatian dari pimpinan untuk menganggarkan program-program pelatihan SIMDA Keuangan secara berkala bagi para pegawai atau staf bidang keuangan, mengingat masih adanya kesenjangan digital (digital divide) pada pegawai atau staf bidang keuangan dalam pengoperasian SIMDA Keuangan. Selain itu, perlu adanya ketegasan dari pimpinan agar pegawai yang mengoperasikan SIMDA Keuangan tidak lalai dan berkomitmen kuat dalam 
menjalankan tugas dan tanggungjawabnya.

Untuk mengatasi kendala kurangnya komitmen pimpinan untuk memperhatikan halhal yang berkaitan dengan kualitas penerapan SIMDA Keuangan di Dinas ESDM Provinsi Jambi, salah satu solusi yang dapat dilakukan yaitu menyuarakan keluhan-keluhan dan saran pengembangan dalam rapat atau diskusi langsung dengan pimpinan, terutama mengenai anggaran pelatihan SIMDA Keuangan, anggaran pemeliharaan perangkat SIMDA, perekrutan pegawai kontrak yang berlatar pendidikan IT, serta peningkatan kualitas pegawai atau staf yang terlibat dalam penyusunan laporan keuangan melalui aplikasi SIMDA Keuangan.

Penelitian ini memiliki keterbatasan yaitu belum mengetahui secara signfikan pengaruh dari faktor pendukung maupun faktor penghambat terhadap efektivitas penerapan SIMDA Keuangan di Dinas ESDM Provinsi Jambi, Oleh karena itu, diharapkan penelitian selanjutnya dapat melakukan penelitian kuantitatif untuk mengetahui ada tidaknya pengaruh atau hubungan yang signifikan antara faktor pendukung maupun faktor penghambat terhadap efektivitas penerapan SIMDA Keuangan. Selain itu, penelitian selanjutnya sebaiknnya melihat beberapa faktor eksternal lain yang dapat mempengaruhi efektivitas, karena mungkin masih banyak faktor eksternal lainnya yang tidak diteliti oleh peneliti.

\section{DAFTAR PUSTAKA}

Agnes, M.D. Kewas, Herman Karamoy, dan Linda Lambey. 2019. Analisis Kendala Pengimplementasian Pendapatan pada SIMDA Keuangan di Pemerintah Provinsi Sulawesi Utara. Artikel Penelitian, Fakultas Ekonomi dan Bisnis Universitas Sam Ratulangi

Edward, George C. 2011. Implementing Public Policy, Washington

Febria, P.D., Yasril Yunus, dan Nora Eka Putri. 2018. Efektivitas Penerapan Aplikasi SIMDA Keuangan di Kantor Sekretariat DPRD Kabupaten Tanah Datar. Jurnal Ilmu Administrasi Publik, Vol. 1 (1)

Hardjanto, K., Margaretha Kusuma P., dan Murjoko. 2019. Implementasi Sistem Informasi Manajemen Daerah (SIMDA) Keuangan Berbasis Akrual pada Dinas Pertanian dan Pangan Kota Magelang. Jurnal Teknik Informatika, Vol. 12 (1):1120

Hertanto, Y., Tjahjanulin, D., dan Amin, F. 2016. Sistem Informasi Manajemen Daerah (SIMDA) Keuangan Terhadap Efektivitas Pelaporan Keuangan (Studi pada Badan Pengelolaan Keuangan dan Aset Daerah di Kabupaten Blitar). PUBLISIA (Jurnal Ilmu Administrasi Publik). Vol 1(2). pp 15-24

Hidayat, W.W. 2018. Dasar-Dasar Analisa Laporan Keuangan. Edisi 1. Jakarta: Uwais Inspirasi Indonesia

Madjid, P. I. 2011. Implementasi Sistem Informasi Manajemen Kepagawaian (SIMPEG) Pada Badan Kependudukan dan Keluarga Berencana Nasional. Tesis, Universitas Indonesia, Jakarta

Nugroho, E. 2008. Sistem Informasi Manajemen Konsep, Aplikasi dan Pengembangan. Yogyakarta : Andi

Pangestika, A.L. dan Sari, Y.P. 2016. Efektivitas Penerapan Sistem Informasi Manajemen Daerah (SIMDA) pada Dinas Pendapatan Pengelolaan Keuangan Dan Aset Daerah (DPPKAD) Kabupaten Tegal. Artikel Penelitian, Politeknik Harapan Bersama Tegal

Peraturan Pemerintah Republik Indonesia Nomor 56 Tahun 2005 tentang Sistem Informasi Keuangan Daerah 
Peraturan Menteri Dalam Negeri Nomor 13 tahun 2006, Tentang Pedoman Pengelolaan Keuangan Daerah sebagaimana telah diubah dengan Peraturan Menteri Dalam Negeri Nomor 59 tahun 2007.

Peraturan Pemerintah Republik Indonesia Nomor 60 Tahun 2008 Tentang Sistem Pengendalian Intern Pemerintah

Peraturan Pemerintah Nomor 71 Tahun 2010 tentang Standar Akuntansi Pemerintahan

Pulungan, M.S. 2014. Optimalisasi SIMDA dalam Mewujudkan Pengelolaan Keuangan Daerah Kabupaten Kutai Kartanegara Provinsi Kalimantan Timur yang Lebih Berkualitas. Jurnal Bina Praja, Vol. 6 (4): 269-282

Ramadhan, A. F dan Moentoro, R. K. 2013. Analisis Kendala Implementasi Sistem Informasi Akuntansi Pada Perguruan Tinggi Negeri. Publikasi Materi Seminar Nasional Sistem Informasi Indonesia, 2 - 4 Desember 2013. SESINDO

Saleh, H.R. 2015. Analisis Factor-Faktor Pendukung Dan Kualitas Informasi Penerapan Sistem Informasi Manajemen Daerah (SIMDA) Keuangan Pada Pemerintah Kota Kendari. Naskah Publikasi. Jurusan Akuntansi. Fakultas Ekonomi Dan Bisnis. Universitas Halu Oleo Kendari, Sulawesi Tenggara

Setiaji, W.A. (2017). Faktor-faktor yang Mempengaruhi Kinerja Sistem Informasi Akuntansi (Studi Kasus pada RS. PKU Muhammadiyah Surakarta). Thesis, Universitas Muhammadiyah Surakarta

Shabrina, K.N. (2014). Efektivitas Pengamanan Aset dalam Mewujudkan Akuntabilitas di Pementahan Surabaya. Jurnal Kebijakan dan Manajemen Publik, Vol. 2 (1) 